\title{
THE EFFECT OF PROTEIN DEPLETION ON THE DISTRIBUTION OF PROTEIN SYNTHESIS IN THE DOG
}

\author{
By J. S. GARROW * \\ (From the Medical Research Council, Tropical Metabolism Research Unit, University College \\ of the West Indies, Jamaica, B. W. I.)
}

(Submitted for publication November 3, 1958; accepted March 27, 1959)

A well nourished adult dog can be maintained in nitrogen balance on a synthetic diet which pro-. vides $250 \mathrm{mg}$. of nitrogen as casein and 80 calories per $\mathrm{Kg}$. body weight per day (1). If the protein in this diet is replaced isocalorically with carbohydrate, the dog continues to lose nitrogen in the urine, although at a rate which becomes progressively less. By the sixth week of protein free diet the urinary nitrogen has fallen to about $60 \mathrm{mg}$. per $\mathrm{Kg}$. per day, which appears to be an irreducible minimum. If the animal is still kept on a protein free diet it becomes weak, apathetic, anorexic and edematous; unless it is given protein within about a week of the onset of these signs it dies. If the refeeding of protein is delayed too long the dog may still die although it is retaining nitrogen, or it may recover after a "lag" period. This observation has led to the hypothesis that severe protein depletion may eventually damage the protein synthetic mechanisms and thus lead to an irreversible state of depletion $(2,3)$.

In many tropical countries an analogous state is found in human infants. When they are taken from the breast they are fed a diet relatively adequate in calories but very poor in protein and as a result develop the clinical syndrome of kwashiorkor (4-6). A number of these children, on admission to hospital, fail to respond to protein and electrolyte repletion and die. The mortality rate in this unit is 20 per cent and the cause of death is not clearly defined. Other cases may show a "lag" period before they respond satisfactorily to treatment (6).

The work reported in this paper is an attempt to produce protein depletion of known severity in dogs and to correlate with the degree of depletion some change in protein metabolism detectable by an isotopic tracer technique. This technique was

* Present address: Institute of Aviation Medicine, Royal Aircraft Establishment, Farnborough, Hants, U.K. designed to be used on human cases and it was hoped that the results obtained under controlled conditions in dogs would provide a background for interpreting data obtained under much less precise conditions in children.

The methods used do not give a measure of the total amount of protein synthesized in unit time, but the results suggest that the distribution of synthesis between the various protein pools is altered by depletion. Thus, while the depleted animal may turn over a smaller amount of protein per day than the normal dog, a greater proportion of synthesis occurs in the active protein pools, such as plasma protein.

\section{METHODS}

Eight clinically normal adult dogs were fed a synthetic diet which provided $250 \mathrm{mg}$. nitrogen (as casein) and 80 calories per $\mathrm{Kg}$. body weight per day (1). These dogs were in nitrogen equilibrium and are termed "normal dogs." Each normal dog was injected intravenously with $4 \mathrm{mg}$. T-1824 and approximately $4 \times 10^{6} \mathrm{cpm}$ in 0.5 mg. $\mathrm{S}^{36}$ methionine per $\mathrm{Kg}$. body weight. Four dogs received labeled DL-methionine and four received labeled L-methionine. In each group of four, two were started on a protein free diet on the day of injection and two were started on this diet one week after injection. The protein free diet was obtained by substituting sucrose isocalorically for casein.

The dogs were kept on the protein free diet and reinjected with $\mathrm{T}-1824$ and $\mathrm{S}^{35}$-labeled methionine after intervals of three to 10 weeks; four dogs were injected a third time after a similar interval. In some cases depletion was accelerated by bleeding, but at least a week was allowed between the last bleeding and the time of injection to enable the protein pools to re-equilibrate.

Daily collections were made of urine for 21 days; the feces for each one week period were pooled and the nitrogen content of the collections determined. When depletion was hastened by bleeding, the $\mathrm{N}$ content of the blood removed was also measured. It was therefore possible to follow the cumulative loss of nitrogen on the protein free diet; this is also expressed in Table $I$ as the percentage loss of the initial body nitrogen, on the assumption that the normal dog contains $25.6 \mathrm{Gm}$. N per $\mathrm{Kg}$. body weight. 
TABLE I

Change in body weight and nitrogen content of dogs fed a protein free diet

\begin{tabular}{|c|c|c|c|c|c|c|c|c|c|c|c|}
\hline \multirow{2}{*}{$\begin{array}{c}\text { Expt. } \\
\text { no. }\end{array}$} & \multirow{2}{*}{$\begin{array}{l}\text { Dog } \\
\text { no. }\end{array}$} & \multirow{2}{*}{$\begin{array}{c}\text { Initial } \\
\text { body wt. }\end{array}$} & \multirow{2}{*}{$\begin{array}{l}\text { Days } \\
\text { on } \\
\text { P.F.D.* }\end{array}$} & \multirow{2}{*}{$\begin{array}{l}\text { Body wt. } \\
\text { at time of } \\
\text { injection }\end{array}$} & \multicolumn{4}{|c|}{ Nitrogen lost during period } & \multirow{2}{*}{$\begin{array}{c}\text { Initial† } \\
\text { total } \\
\text { body N }\end{array}$} & \multirow{2}{*}{$\begin{array}{l}\text { Total } \\
\text { N lost }\end{array}$} & \multirow{2}{*}{$\begin{array}{c}\text { Body wt. } \\
\text { lost }\end{array}$} \\
\hline & & & & & Urine & Feces & Blood & Total & & & \\
\hline $\begin{array}{r}9 \\
17\end{array}$ & $\begin{array}{l}178 \\
178\end{array}$ & $\begin{array}{l}K g . \\
4.95 \\
4.95\end{array}$ & $\begin{array}{l}22 \\
57\end{array}$ & $\begin{array}{c}K g . \\
4.6 \\
4.3\end{array}$ & $\begin{array}{l}G m . \\
13.2 \\
25.8\end{array}$ & $\begin{array}{r}G m . \\
2.9 \\
6.4\end{array}$ & $\begin{array}{l}G m . \\
0 \\
7.1\end{array}$ & $\begin{array}{l}G m . \\
16.1 \\
39.3\end{array}$ & $\begin{array}{l}\text { Gm. } \\
127 \\
127\end{array}$ & $\begin{array}{c}\% \\
7.9 \\
31.0\end{array}$ & $\begin{array}{c}\% \\
7.0 \\
13.2\end{array}$ \\
\hline $\begin{array}{l}10 \\
19\end{array}$ & $\begin{array}{l}201 \\
201\end{array}$ & $\begin{array}{l}5.9 \\
5.9\end{array}$ & $\begin{array}{l}22 \\
61\end{array}$ & $\begin{array}{l}5.6 \\
5.1\end{array}$ & $\begin{array}{l}13.0 \\
27.6\end{array}$ & $\begin{array}{l}3.9 \\
8.9\end{array}$ & $\begin{array}{l}0 \\
6.8\end{array}$ & $\begin{array}{l}16.9 \\
43.3\end{array}$ & $\begin{array}{l}151 \\
151\end{array}$ & $\begin{array}{r}8.9 \\
28.7\end{array}$ & $\begin{array}{r}5.1 \\
13.6\end{array}$ \\
\hline 15 & 206 & 11.7 & 28 & 11.0 & 30.8 & 11.2 & 20.7 & 62.7 & 300 & 20.9 & 6.2 \\
\hline $\begin{array}{l}11 \\
18\end{array}$ & $\begin{array}{l}179 \\
179\end{array}$ & $\begin{array}{l}5.2 \\
5.2\end{array}$ & $\begin{array}{l}29 \\
64\end{array}$ & $\begin{array}{l}4.6 \\
4.5\end{array}$ & $\begin{array}{l}16.3 \\
25.6\end{array}$ & $\begin{array}{l}4.0 \\
8.1\end{array}$ & $\begin{array}{l}0 \\
5.6\end{array}$ & $\begin{array}{l}20.3 \\
39.3\end{array}$ & $\begin{array}{l}133 \\
133\end{array}$ & $\begin{array}{l}15.5 \\
29.6\end{array}$ & $\begin{array}{l}11.5 \\
13.4\end{array}$ \\
\hline $\begin{array}{l}12 \\
20\end{array}$ & $\begin{array}{l}203 \\
203\end{array}$ & $\begin{array}{l}5.5 \\
5.5\end{array}$ & $\begin{array}{l}29 \\
68\end{array}$ & $\begin{array}{l}4.6 \\
4.5\end{array}$ & $\begin{array}{l}19.7 \\
34.3\end{array}$ & $\begin{array}{r}5.3 \\
10.3\end{array}$ & $\begin{array}{l}0 \\
8.6\end{array}$ & $\begin{array}{l}25.0 \\
53.2\end{array}$ & $\begin{array}{l}141 \\
141\end{array}$ & $\begin{array}{l}17.7 \\
37.7\end{array}$ & $\begin{array}{l}16.4 \\
18.2\end{array}$ \\
\hline 16 & 207 & 10.2 & 35 & 9.2 & 28.7 & 8.1 & 18.2 & 55.0 & 261 & 21.1 & 9.7 \\
\hline 13 & 175 & 6.8 & 45 & 6.2 & 25.8 & 11.2 & 0 & 37.0 & 167 & 22.1 & 8.9 \\
\hline 14 & 212 & 6.2 & 52 & 5.7 & 26.9 & 10.4 & 0 & 37.3 & 159 & 23.4 & 8.1 \\
\hline
\end{tabular}

* P.F.D. = protein free diet.

† It is assumed that the body initially contained $25.6 \mathrm{Gm}$. nitrogen per $\mathrm{Kg}$.

Venous blood samples were taken into heparin at onequarter, one, two, four, six and eight hours after injection and then daily for one week. Plasma volume was measured in the usual way, by extrapolation to zero time from the dye concentrations in samples taken one-quarter and one hour after injection. Total plasma protein concentration was calculated from the $\mathrm{N}$ content of the samples taken just before each injection. Protein was taken as $\mathrm{N} \times 6.25$ without allowance for nonprotein nitrogen.

For radioactivity measurements, plasma proteins were precipitated with 5 per cent trichloracetic acid (TCA). The activity of the supernatant was measured in samples taken up to eight hours after injection; these results are expressed as "cpm per ml. protein free plasma." In later samples the activity became so low that counts were not done on the supernatants.

The precipitated proteins were washed twice with 5 per cent TCA and then dissolved in N sodium hydroxide to give an approximately 5 per cent solution of protein. The activity in $0.25 \mathrm{ml}$. samples of this solution was measured. The $\mathrm{N}$ content was determined by microKjeldahl and the results expressed as cpm per $\mathrm{mg}$. of protein. These results represent the mixed proteins of plasma; no measurements were made on separated plasma protein fractions. Samples of the daily urine collections were counted but no counts were done on feces.

Radioactivity was measured with a gas flow counter, using 98.7 per cent helium and 1.3 per cent butane. Samples were prepared, dried and counted in disposable stainless steel cups. The results have been corrected for background, radioactive decay and self-absorption and are calculated to a standard dosage of $4.0 \times 10^{\circ} \mathrm{cpm}$ per $\mathrm{Kg}$. body weight. When second and third injections were made, the residual activity in samples taken immediately before reinjection was subtracted from subsequent values. This residual activity was less than 10 per cent of the dose administered and its rate of change less than 10 per cent over the time period of study; it has therefore been treated as a constant.

The term "specific activity" has been used in the text to mean radioactivity (from $\mathrm{S}^{35}$ ) per $\mathrm{mg}$. nitrogen. Strictly this is incorrect, but provided the sulphur/nitrogen ratio in the protein is constant the figure given is proportional to the true specific activity.

\section{RESULTS}

\section{The extent of the depletion}

Table I shows the estimated proportion of body $\mathrm{N}$ lost at various stages of depletion in relation to the loss of body weight. After 50 to 60 days on the protein free diet about 30 per cent of body $\mathrm{N}$ had been lost, whereas the weight fell by only 13 to 18 per cent. The discrepancy is presumably due to the accumulation of edema fluid ( 7$)$, even though this could not be detected clinically, except in the very late stages. The distribution of the $\mathrm{N}$ loss between urine and feces is also shown in Table I. 


\section{Total circulating plasma protcin}

In four dogs successive measurements were made of plasma volume and plasma protein concentration, from which could be calculated the total amount of plasma protein in the intravascular compartment (Table II). It appears that in the later stages of depletion there is a rapid reduction in the amount of circulating protein, which outstrips the loss of total body $\mathrm{N}$. This fits in with the clinical impression that in kwashiorkor the fall in plasma protein concentration is a late event in the development of the disease.

\section{Disappearance of nonprotein-bound activity from plasma}

The mean values and ranges for the samples taken up to eight hours after injection are shown in Figure 1. The curve was not significantly altered whether the dog was receiving protein or not, whether its protein stores were full or depleted, or whether DL- or L-methionine was given. The results have therefore been averaged.

\section{Incorporation of labeled methionine into plasma protein}

Figures 2 and 3 show the activity per mg. of plasma protein in samples taken one, two, four, six and eight hours after injection, in dogs given DL- and L-methionine. Again there is no apparent difference between the results with the DL- and L-forms.

The shape of the curve is similar in all experiments and reaches a maximum in about six hours. The height of the curve, however, was greatly increased in the depleted dogs (Table II, Column 9). In individual dogs the peak activity progressively rises with increasing depletion. Comparison between different dogs suggests that this process does not go on indefinitely, but may reach a maxi-

TABLE II

The effect of protein depletion on the size and activity of the intravascular plasma protein pool and on the apparent half-life of plasma protein in dogs injected with $S^{35}$-methionine

\begin{tabular}{|c|c|c|c|c|c|c|c|c|c|c|}
\hline $\begin{array}{l}\text { Dog } \\
\text { no. }\end{array}$ & $\begin{array}{l}\text { Days on } \\
\text { P.F.D.* }\end{array}$ & $\underset{\text { lost }}{\text { Body } N}$ & $\begin{array}{l}\text { Plasma } \\
\text { vol. }\end{array}$ & $\begin{array}{l}\text { Plasma } \\
\text { protein }\end{array}$ & $\begin{array}{c}6 \\
\text { Total } \\
\text { plasma } \\
\text { protein } \ddagger\end{array}$ & $\begin{array}{c}7 \\
\begin{array}{c}\text { Plasma } \\
\text { protein } \\
\text { lost } \ddagger\end{array}\end{array}$ & $\begin{array}{c}\text { Isomer } \\
\text { injected }\end{array}$ & $\begin{array}{c}9 \\
\text { Peak } \\
\text { plasma } \\
\text { protein } \\
\text { activity }\end{array}$ & $\begin{array}{c}10 \\
\text { Total } \\
\text { activity } \\
\text { in plasma } \\
\text { protein } \ddagger\end{array}$ & $\begin{array}{c}11 \\
\text { Apparent } \\
\text { plasma } \\
\text { protein } \\
\text { half-life }\end{array}$ \\
\hline $\begin{array}{l}178 \\
178 \\
178\end{array}$ & $\begin{array}{r}0 \\
22 \\
57\end{array}$ & $\begin{array}{c}\% \\
0 \\
7.9 \\
31.0\end{array}$ & $\begin{array}{l}m l . \\
324 \\
310 \\
271\end{array}$ & $\begin{array}{c}\mathrm{Gm} . / 100 \mathrm{ml} . \\
6.12 \\
5.81 \\
3.54\end{array}$ & $\begin{array}{r}G m . \\
19.8 \\
18.0 \\
9.6\end{array}$ & $\begin{array}{c}\% \\
0 \\
9.2 \\
51.5\end{array}$ & $\begin{array}{l}\text { DL } \\
\text { DL } \\
\text { DL }\end{array}$ & $\begin{array}{c}c p m / m g . \\
41.5 \\
70.6 \\
120.7\end{array}$ & $\begin{array}{l}\% \\
4.15 \\
6.91 \\
7.37\end{array}$ & $\begin{array}{l}\text { days } \\
13.6 \\
16.8 \\
12.8\end{array}$ \\
\hline $\begin{array}{l}201 \\
201 \\
201\end{array}$ & $\begin{array}{r}0 \\
22 \\
61\end{array}$ & $\begin{array}{r}0 \\
8.9 \\
28.7\end{array}$ & $\begin{array}{l}346 \\
333 \\
343\end{array}$ & $\begin{array}{l}7.04 \\
5.37 \\
3.54\end{array}$ & $\begin{array}{l}24.4 \\
17.8 \\
12.2\end{array}$ & $\begin{array}{c}0 \\
27.0 \\
50.0\end{array}$ & $\begin{array}{l}\text { DL } \\
\text { L } \\
\text { L }\end{array}$ & $\begin{array}{r}41.8 \\
84.8 \\
112.2\end{array}$ & $\begin{array}{l}4.33 \\
6.74 \\
6.71\end{array}$ & $\begin{array}{c}13.4 \\
\text { Not measured } \\
16.0\end{array}$ \\
\hline $\begin{array}{l}179 \\
179 \\
179\end{array}$ & $\begin{array}{r}0 \\
29 \\
64\end{array}$ & $\begin{array}{c}0 \\
15.5 \\
29.6\end{array}$ & $\begin{array}{l}339 \\
370 \\
292\end{array}$ & $\begin{array}{l}6.10 \\
5.00 \\
3.38\end{array}$ & $\begin{array}{r}20.7 \\
18.5 \\
9.9\end{array}$ & $\begin{array}{c}0 \\
10.7 \\
52.1\end{array}$ & $\begin{array}{l}\text { DL } \\
\text { DL } \\
\text { DL }\end{array}$ & $\begin{array}{r}54.1 \\
73.4 \\
132.0\end{array}$ & $\begin{array}{l}5.38 \\
7.40 \\
6.72\end{array}$ & $\begin{array}{l}19.5 \\
36.0 \\
15.3\end{array}$ \\
\hline $\begin{array}{l}203 \\
203 \\
203\end{array}$ & $\begin{array}{r}0 \\
29 \\
68\end{array}$ & $\begin{array}{l}0 \\
17.7 \\
37.7\end{array}$ & $\begin{array}{l}296 \\
363 \\
261\end{array}$ & $\begin{array}{l}6.22 \\
4.64 \\
3.48\end{array}$ & $\begin{array}{r}18.4 \\
16.8 \\
9.1\end{array}$ & $\begin{array}{l}0 \\
8.8 \\
50.6\end{array}$ & $\begin{array}{l}\text { DL } \\
\text { L } \\
\text { L }\end{array}$ & $\begin{array}{r}50.4 \\
84.3 \\
103.2\end{array}$ & $\begin{array}{l}4.22 \\
7.70 \\
5.22\end{array}$ & $\begin{array}{c}9.0 \\
\text { Not measured } \\
18.3\end{array}$ \\
\hline $\begin{array}{l}206 \\
206\end{array}$ & $\begin{array}{r}0 \\
28\end{array}$ & $\begin{array}{c}0 \\
20.9\end{array}$ & \multicolumn{4}{|c|}{$\begin{array}{l}\text { Not measured } \\
\text { Not measured }\end{array}$} & $\begin{array}{l}\mathbf{L} \\
\mathrm{L}\end{array}$ & $\begin{array}{r}56.0 \\
111.5\end{array}$ & & $\begin{array}{l}13.8 \\
20.8\end{array}$ \\
\hline $\begin{array}{l}175 \\
175\end{array}$ & $\begin{array}{r}0 \\
45\end{array}$ & $\begin{array}{c}0 \\
22.1\end{array}$ & \multicolumn{4}{|c|}{$\begin{array}{l}\text { Not measured } \\
\text { Not measured }\end{array}$} & $\begin{array}{l}\text { L } \\
\text { DL }\end{array}$ & $\begin{array}{l}46.5 \\
97.7\end{array}$ & & $\begin{array}{c}16.6 \\
\text { Not measured }\end{array}$ \\
\hline $\begin{array}{l}207 \\
207\end{array}$ & $\begin{array}{r}0 \\
35\end{array}$ & $\begin{array}{c}0 \\
21.1\end{array}$ & \multicolumn{4}{|c|}{$\begin{array}{l}\text { Not measured } \\
\text { Not measured }\end{array}$} & $\begin{array}{l}\mathbf{L} \\
\mathbf{L}\end{array}$ & $\begin{array}{r}56.7 \\
128.8\end{array}$ & & $\begin{array}{l}16.4 \\
22.3\end{array}$ \\
\hline $\begin{array}{l}212 \\
212\end{array}$ & $\begin{array}{r}0 \\
52\end{array}$ & $\begin{array}{c}0 \\
23.4\end{array}$ & \multicolumn{4}{|c|}{$\begin{array}{l}\text { Not measured } \\
\text { Not measured }\end{array}$} & $\begin{array}{l}\mathrm{L} \\
\mathrm{DL}\end{array}$ & $\begin{array}{r}65.7 \\
133.3\end{array}$ & & $\begin{array}{c}13.7 \\
\text { Not measured }\end{array}$ \\
\hline
\end{tabular}

* P.F.D. = protein free diet.

$\dagger$ Refers to days on diet and $\mathbf{N}$ lost at the time of the injection of labeled methionine.

\$ Refers to plasma protein in intravascular compartment. 


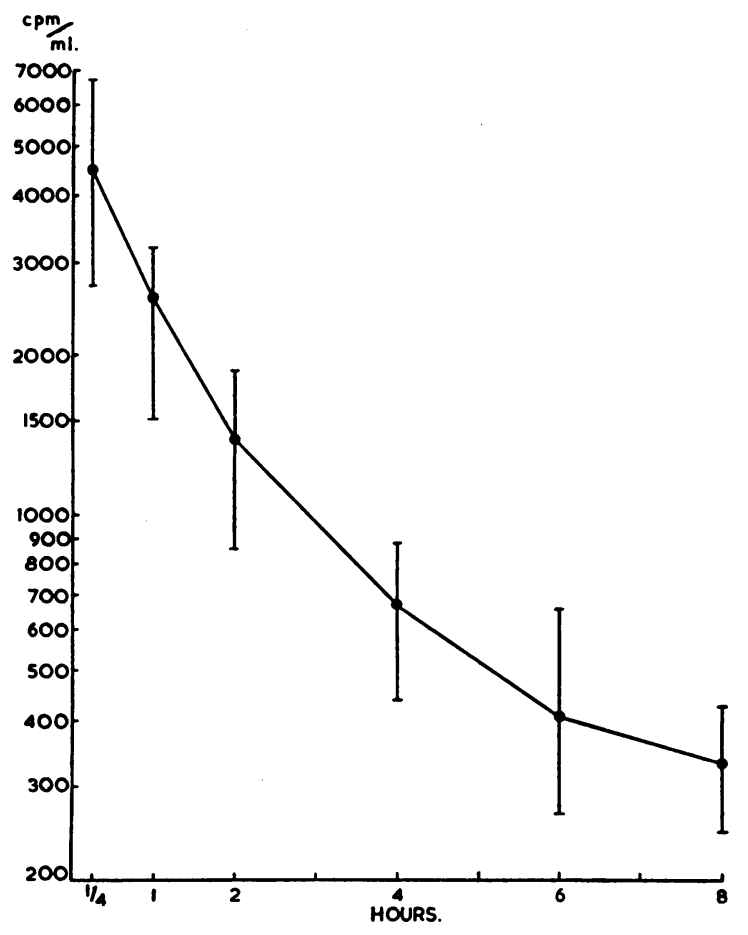

Fig. 1. Disappearance of Radioactivity from the Protein Free Fraction of Plasma: "Free MethioNINE"

The curve is drawn through the mean values, and vertical bars indicate the range.

mum at about 20 per cent depletion of body N. In four dogs (Nos. 206, 175, 207 and 212, Table II), with an average depletion of 22 per cent of body $\mathrm{N}$, the mean peak activity was $118 \mathrm{cpm}$ per $\mathrm{mg}$. plasma protein. In four other dogs (Nos. 178, 201, 179 and 203), with an average depletion of 32 per cent of body $\mathrm{N}$, the mean peak was $117 \mathrm{cpm}$ per mg. plasma protein.

\section{Plasma protein decay curve}

The apparent half-lives for the mixed plasma proteins are shown in Table II, Column 11. There is no consistent difference between normal and depleted dogs.

\section{Excretion of labeled sulfur}

Figures 4 and 5 show the daily excretion, expressed as per cent of the dose remaining in the body, in dogs given DL- and L-methionine. Again, there is little difference between normal and depleted animals. The excretion is perhaps a little more rapid in the depleted dogs, but the numbers are too few for the differences to be established with certainty. The specific activity (cpm per mg. N) of urine appears to reflect fairly closely that of plasma protein (Table III).

\section{DISCUSSION}

The striking difference between depleted and normal dogs is the increase in plasma protein specific activity as depletion progresses (Table II, Column 9). The higher specific activity can result from two factors: a reduction in size of the plasma protein pool, or a larger proportion of labeled molecules entering the pool. The first factor undoubtedly operates in depleted dogs; Table II, Column 7, shows that when 30 per cent of body $\mathrm{N}$ has been lost the circulating plasma protein falls to about half the normal amount. This, however, is not enough by itself to explain the increased specific activity of the plasma proteins, since Column 10 of Table II shows that in depleted dogs a larger proportion of the radioactivity was incorporated in plasma protein. The proportion is greatest when about 25 per cent of body $\mathrm{N}$ has been lost and thereafter appears to decrease again. Thus, if the proportion of dose incorporated in intravascular plasma protein in normal dogs is taken as unity, the four dogs in which measurements were repeated incorporated 1.60 times as much in moderate depletion and 1.44 times as much in severe depletion.

Yuile, Lucas, Neubecker and Whipple (8) reported that in dogs depleted by plasmapheresis as well as by a low protein diet the reduction in the extravascular extracellular protein pool was much greater than the reduction in circulating plasma protein. Their method of calculating the extravascular pool size is not given in detail. In the present experiments the size of this pool was not measured. However, it does not seem possible that a disproportionate reduction in the extravascular pool could account for the increased specific activity of the intravascular protein at six to eight hours after injection (Table II) since from the available data it probably takes at least two days for the two pools to reach equilibrium $(9,10)$.

Intravascular plasma protein is the only protein pool which can be quantitatively measured. The plasma volume, plasma protein concentration and 
plasma protein specific activity can all be measured and hence the absolute quantity of radioactivity in intravascular protein can be calculated and expressed as a percentage of the administered dose. The result of this calculation is shown in Column
10 of Table II for the four dogs which were injected three times at varying stages of depletion. In the normal dogs an average of 4.5 per cent of the injected dose is accounted for by intravascular protein; the averages on the second and third in-

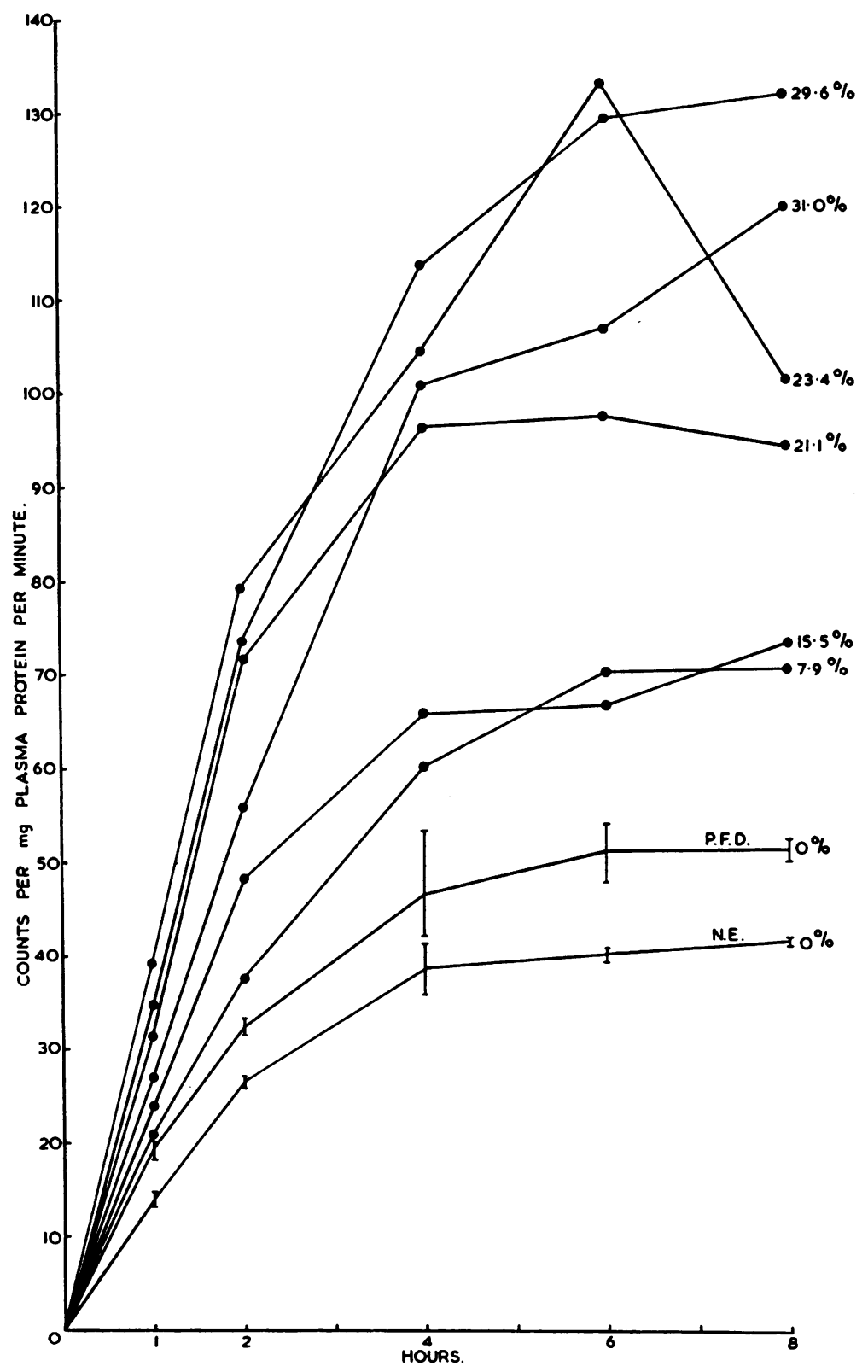

Fig. 2. Plasma Protein Activity in Dogs Given dL-S ${ }^{35}$-Methionine INTRAVENOUSLY

Curve N.E. shows average values for two dogs in nitrogen equilibrium and Curve P.F.D. for two on protein free diet. The remaining curves are for dogs on protein free diet. The percentage of total body protein by which the dog had been depleted is shown to the right of each curve. 


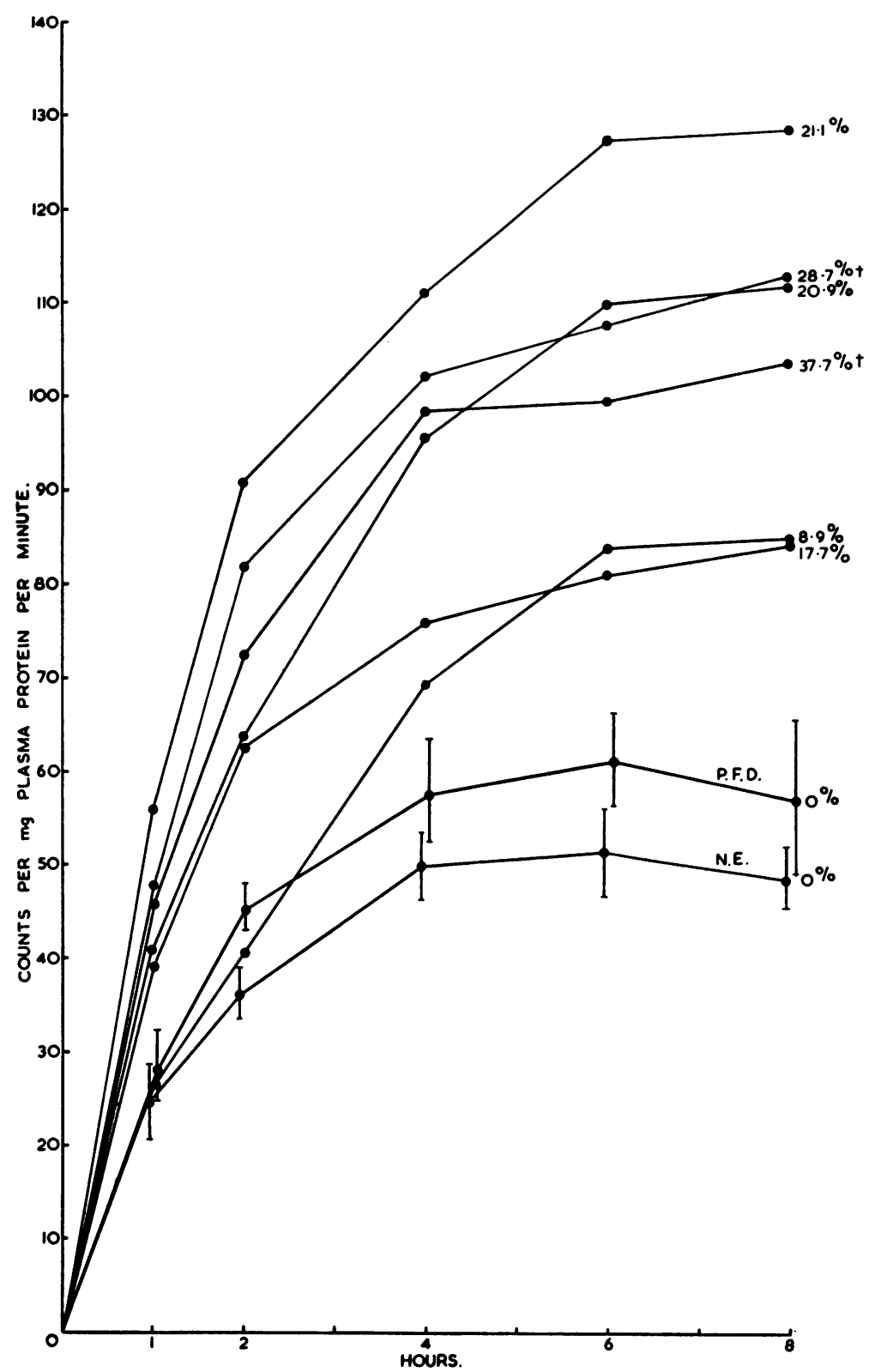

Fig. 3. Plasma Protein Activity in Dogs Given L-S ${ }^{35}$-Methionine INTRAVENOUSLY

Curves are labeled as in Figure 2. The mark + indicates that these dogs died eight days after injection.

jections are 7.2 per cent and 6.5 per cent, respectively. It appears that with depletion an increasing proportion of the dose goes into intravascular protein, and that this effect is due to a change in the distribution of synthesis and not merely to an alteration in pool sizes, for the reason given above.

Something of the behavior of the remainder of the radioactive dose can be inferred from a consideration of the excretion of nitrogen and radioactivity in the urine and from the decrease in activity of the plasma protein. In the present experiments the values for apparent plasma protein half-life (Table II) are variable and show no consistent change with depletion. (The figures are 


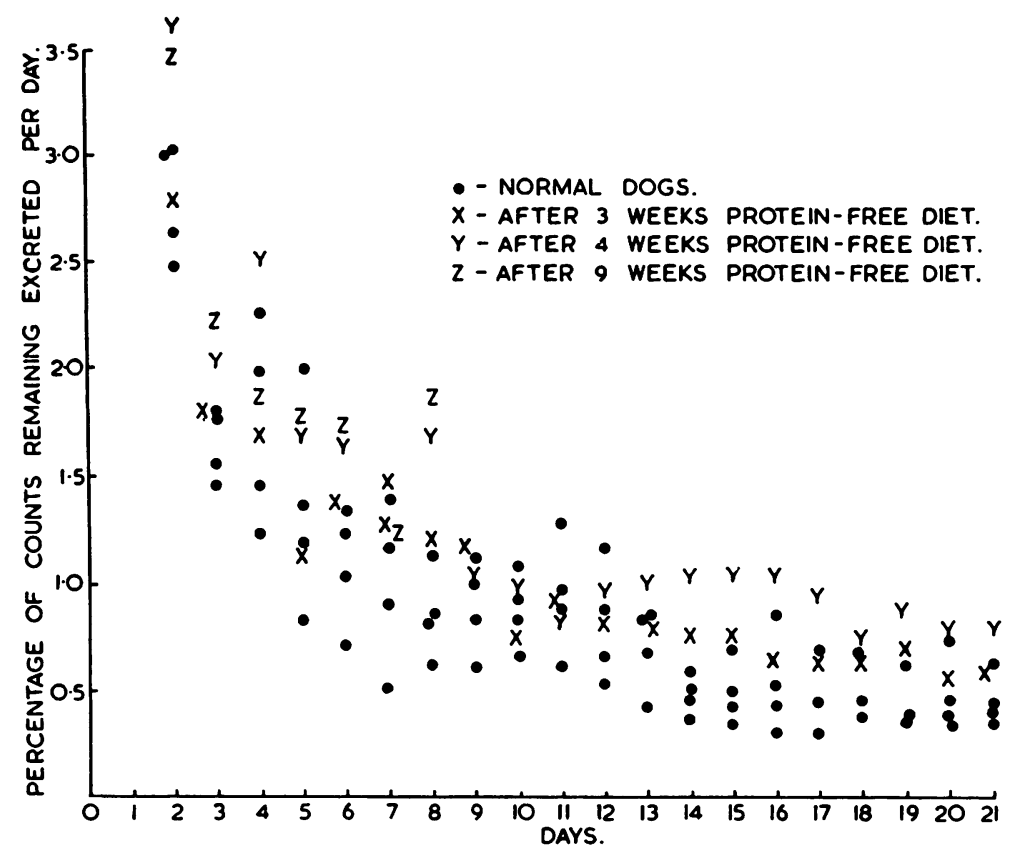

Fig. 4. Effect of Depletion on the Excretion of Labeled Sulfur in the Urine After Intravenous Injection of DL-Methionine

not true half-lives owing to the reutilization of the radioactive label and to the fact that plasma proteins are a mixture of fractions of various halflives.) Studies with $\mathrm{I}^{131}$-labeled albumin in pro- tein depleted children in Mexico (11) and in Jamaica (12) have also given no indication of any change in half-life.

With progressing depletion and a protein free

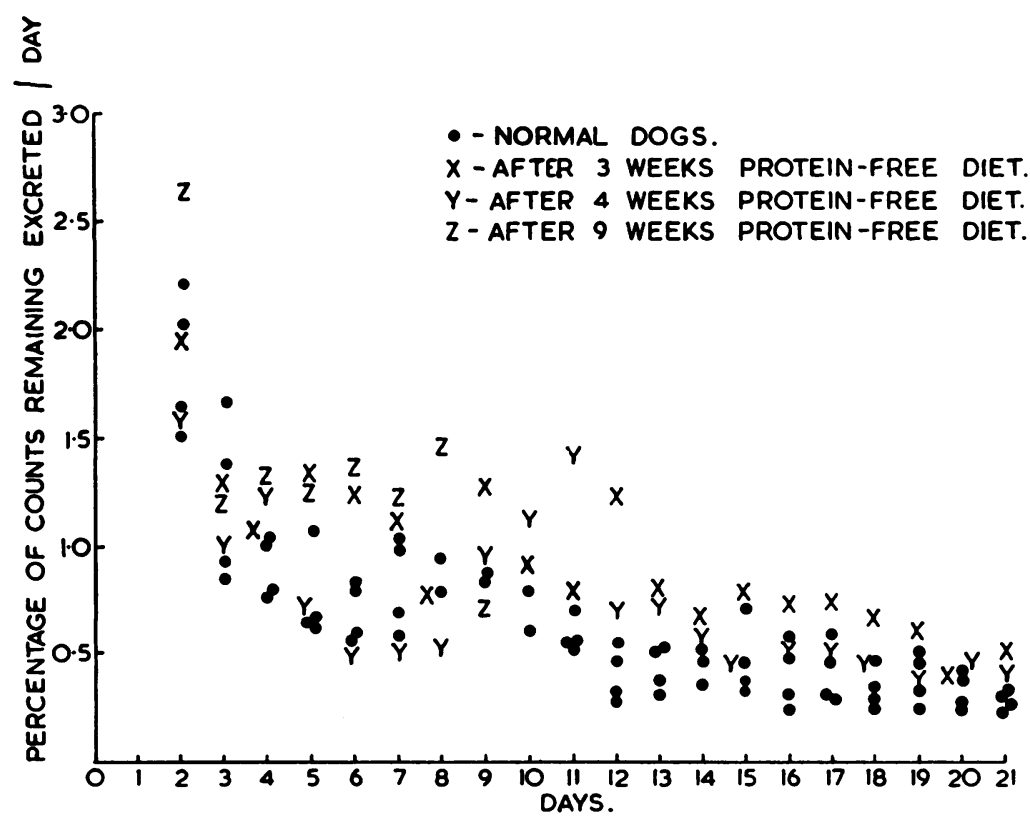

Fig. 5. Effect of Depletion on the Excretion of Labeled Sulfur in the Urine After Intravenous Injection of L-Methionine 
TABLE III

Comparison of specific activity in plasma proteins and in urine in normal and depleted dogs on the seventh day after the injection of labeled methionine

\begin{tabular}{|c|c|c|c|c|c|}
\hline Dog no. & $\begin{array}{l}\text { Days on } \\
\text { P.F.D. }\end{array}$ & $\begin{array}{c}\text { Body } N \\
\text { lost }\end{array}$ & $\begin{array}{l}\text { Plasma } \\
\text { proteins } \\
\text { on 7th day }\end{array}$ & $\begin{array}{l}\text { Urine } \\
\text { on 7th } \\
\text { day }\end{array}$ & $\begin{array}{l}\text { "Average" } \\
\text { activity } \\
\text { on 7th day* }\end{array}$ \\
\hline 178 & $\begin{array}{r}0 \\
22 \\
57\end{array}$ & $\begin{array}{l}\% \\
0 \\
7.9 \\
31\end{array}$ & 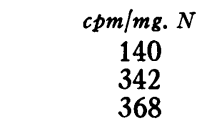 & 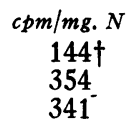 & $\begin{array}{c}\text { cpm/mg. } N \\
117 \\
128 \\
153\end{array}$ \\
\hline 201 & $\begin{array}{r}0 \\
22 \\
66\end{array}$ & $\begin{array}{r}0 \\
8.9 \\
28.7\end{array}$ & $\begin{array}{l}140 \\
285 \\
375\end{array}$ & $\begin{array}{l}132 \dagger \\
341 \\
355\end{array}$ & $\begin{array}{l}118 \\
130 \\
146\end{array}$ \\
\hline 179 & $\begin{array}{r}0 \\
29 \\
64\end{array}$ & $\begin{array}{c}0 \\
15.5 \\
29.6\end{array}$ & $\begin{array}{l}195 \\
455 \\
450\end{array}$ & $\begin{array}{l}279 \\
426 \\
453\end{array}$ & $\begin{array}{l}123 \\
127 \\
150\end{array}$ \\
\hline 203 & $\begin{array}{r}0 \\
29 \\
68\end{array}$ & $\begin{array}{c}0 \\
17.7 \\
37.7\end{array}$ & $\begin{array}{l}156 \\
355 \\
430\end{array}$ & $\begin{array}{l}143 \\
240 \\
305\end{array}$ & $\begin{array}{l}122 \\
123 \\
159\end{array}$ \\
\hline 206 & $\begin{array}{r}0 \\
28\end{array}$ & $\begin{array}{c}0 \\
20.9\end{array}$ & $\begin{array}{l}175 \\
390\end{array}$ & $\begin{array}{l}189 \dagger \\
371\end{array}$ & $\begin{array}{l}115 \\
142\end{array}$ \\
\hline 207 & $\begin{array}{r}0 \\
35\end{array}$ & $\begin{array}{c}0 \\
21.1\end{array}$ & $\begin{array}{l}172 \\
418\end{array}$ & $\begin{array}{l}157 \\
502\end{array}$ & $\begin{array}{l}122 \\
138\end{array}$ \\
\hline
\end{tabular}

* Total radioactivity remaining on the seventh day (cpm) divided by total body nitrogen on seventh day (mg.). $\dagger$ These dogs were receiving $0.25 \mathrm{Gm}$. casein $\mathrm{N}$ per $\mathrm{Kg}$. per day and were in $\mathrm{N}$ equilibrium. The remaining dogs were on a protein free diet.

diet the excretion of nitrogen in the urine decreased, while the excretion of radioactivity tended slightly to increase (Figures 4 and 5).

Data concerning six of the dogs on the seventh day after their injections are summarized in Table III. For purposes of the following discussion it is assumed that: a) The exchange of free with protein-bound methionine is complete by the seventh day after injection; $b$ ) Any labeled sulfur not excreted in the urine by the seventh day has been incorporated in protein; and c) The behavior of methionine is typical of all amino acids.

The specific activities of urine and plasma protein are remarkably similar and both increase greatly with depletion. However, that this cannot be true of the great majority of body protein is shown by the last column in Table III, the "average activity." This figure is obtained by dividing the total radioactivity (cpm) remaining on the seventh day by the total body nitrogen on that day (mg.) and it would therefore be the specific activity of any protein sample from that dog if all the protein were equally labeled at that time. In the normal dog the urine, plasma protein and "average" activities are not greatly different
(Table III). In the depleted dog the urine and plasma specific activities are two or three times greater than the "average," so there must necessarily be some protein of less than average activity.

No doubt the various body proteins have a continuous spectrum of activities from high to low, but it is convenient to group them into a high or low activity pool. Since the urine of the depleted dog shows a high specific activity the urinary nitrogen must have been derived from the breakdown of a high activity protein pool. The plasma protein pool itself is too small to supply the excreted nitrogen. Even the most severely depleted dog excreted about $80 \mathrm{mg}$. of nitrogen per $\mathrm{Kg}$. body weight per day, which in a $5 \mathrm{Kg}$. dog represents the destruction of about $2.5 \mathrm{Gm}$. of protein daily in a dog with only about $10 \mathrm{Gm}$. of intravascular plasma protein. If the urinary nitrogen was derived from plasma protein alone and the plasma protein was replaced from a large pool of about average activity, the plasma protein specific activity would decline rapidly and this has not been found to be the case. It is therefore necessary to postulate a fairly large high activity pool 
with two or three times the average activity. Clearly this implies that the activity of the low pool must be considerably lower than the "average activity" and relatively little of the urinary nitrogen can be derived from catabolism of this low activity pool; otherwise, by dilution, the specific activity of the urine would be reduced.

Some animal experiments support the idea that there is an alteration in the distribution of protein metabolism with depletion. Waterlow (13) has found that protein-depleted rats incorporate a greater proportion of labeled methionine in visceral protein and a smaller proportion in carcass protein (muscle, skin and bone) than do normally fed rats. A similar difference is found between rats having 15 per cent or 30 per cent of casein in the diet (14).

During protein depletion two related types of change are taking place in the animal. The first is the sacrifice of protein from body tissues. There is information from many sources that this affects different organs and tissues to different extents and that the distribution of depletion varies with the duration of protein lack. Liver protein bears the greater part of the loss at first (14-17). Some plasma protein is also sacrificed, the albumin more rapidly than the globulin fractions (7). When these "labile" stores are exhausted the loss is borne by the large mass of protein of slower turnover, which is used to maintain plasma protein (18). Changes of this kind are detectable by measurements of the protein contents of organs and represent an anatomical redistribution of protein.

The second type of change is physiological and is detectable only by tracer studies in the intact animal. Just as the site of protein destruction changes with progressive depletion, so does the distribution of protein synthesis. From the present results we may think of the protein-deprived animal drawing in its metabolic frontiers and concentrating its synthetic resources on a diminishing proportion of its protein mass, which presumably is the most important for its survival. There is some indication that this compensatory mechanism tends to break down as depletion progresses. The proportion of labeled amino acid incorporated into plasma protein was slightly less in severe than in moderate depletion. It is perhaps significant that the loss of plasma protein (13.9 per cent) is approximately proportional to that of whole body protein (12.5 per cent) in the first month or so of protein deprivation, but in the second month the plasma protein loss is much greater (51.1 per cent against 31.7 per cent; average figures from Table II, Column 6).

Whipple, Miller and Robscheit-Robbins have shown that in very severe depletion the raiding of tissue protein decreases, and have suggested that this is due to loss of cell enzymes (18). This enzyme loss has been demonstrated in proteindepleted animals and in malnourished children $(19,20)$. The fact that death may occur in a depleted animal even when it is being re-fed and is apparently retaining nitrogen $(2,3,6,18)$ indicates that protein loss alone is not the cause of death. Some damage to the metabolic machinery must occur and this damage is not detectable by gross nitrogen balance studies. It is suggested that the concept of protein depletion is incomplete if it is based only on the consideration of the state of the protein stores. The redistribution of protein metabolism, as revealed by tracer studies, may be physiologically a more important factor.

\section{SUM MARY}

1. $\mathrm{S}^{35}$-labeled methionine was injected into normal and protein-depleted dogs. The degree of depletion was calculated from the cumulative negative nitrogen balance on a protein free diet.

2. The activity of the mixed plasma proteins was measured for eight days after injection and the activity of the urine for 21 days.

3. In both normal and depleted dogs the peak plasma protein activity was reached at about six hours after injection. Depletion did not alter the apparent half-life of the plasma proteins.

4. With increasing depletion, up to a loss of some 25 per cent of body $\mathrm{N}$, there was a marked increase in peak specific activity of the plasma proteins (cpm per mg. N). With greater degrees of depletion this trend tended to be reversed.

5. The increased specific activity of the plasma proteins in depleted dogs can be explained partly, but not entirely, by a reduction in the size of the circulating protein pool. Even when this is taken into account, it is shown that a larger proportion of the injected dose is incorporated in plasma protein in the depleted than in the normal animal. 
6. The reasons for this are discussed: It is suggested that the effect represents a concentration of protein synthesis in the more essential organs, at the expense of the less essential, such as muscle. In the most advanced stages of protein depletion this compensatory mechanism may break down.

\section{ACKNOWLEDGMENTS}

I am most grateful to Dr. J. B. Allison, Director of the Bureau of Biological Research of Rutgers University, who provided the animals, diets and laboratory facilities for this investigation and who was also most generous in his advice and encouragement. I also thank $R$. Wannemacher, Jr. of the Bureau for his valuable assistance with the experiments and Dr. J. C. Waterlow, Director of the Tropical Metabolism Research Unit, for his interest and guidance.

\section{REFERENCES}

1. Allison, J. B., Anderson, J. A., and Seeley, R. D. The determination of the nitrogen balance index in normal and hypoproteinemic dogs. Ann. N. Y. Acad. Sci. 1946, 47, 245.

2. Robscheit-Robbins, F. S., Miller, L. L., and Whipple, G. H. Plasma protein and hemoglobin production. Deletion of individual amino acids from growth mixture of ten essential amino acids. Significant changes in urinary nitrogen. J. exp. Med. 1947, 85, 243.

3. Allison, J. B. Symposia on Nutrition. Vol. 2. Plasma proteins. Springfield, C. C Thomas, 1950, p. 123.

4. Waterlow, J. C. Fatty Liver Disease in Infants in the British West Indies. Medical Research Council (Great Britain) Special Report Series, No. 263. H. M. Stationery Office, 1948.

5. Trowell, H. C., Davies, J. N. P., and Dean, R. F. A. Kwashiorkor. London, Arnold, 1954.

6. Food \& Agriculture Organization of the U. N. Proceedings of a Conference on Protein Malnutrition in Jamaica (1953), J. C. Waterlow, Ed. Cambridge, University Press, 1955.

7. Allison, J. B., Seeley, R. D., Brown, J. H., and Ferguson, F. P. Some effects of depletion and re- pletion in proteins on body fluids in adult dogs. Proc. Soc. exp. Biol. (N. Y.) 1946, 63, 214.

8. Yuile, C. L., Lucas, F. V., Neubecker, R. D., and Whipple, G. H. Reduction of extravascular-extracellular proteins in protein-depleted dogs. Fed. Proc. 1955, 14, 424.

9. McFarlane, A. S. Use of labelled plasma proteins in the study of nutritional problems. Progr. Biophysics 1957, 7, 115.

10. Gitlin, D. Distribution dynamics of circulating and extravascular $\mathrm{I}^{131}$ plasma proteins. Ann. N. Y. Acad. Sci. 1957, 70, 122.

11. Gitlin, D., Cravioto, J., Frenk, S., Montano, E. L., Galvan, R. R., Gomez, F., and Janeway, C. A. Albumin metabolism in children with protein malnutrition. J. clin. Invest. 1958, 37, 682.

12. Garrow, J. S., and Waterlow, J. C. Observations on Evans blue dye as a tracer for human plasma albumin. Clin. Sci. 1959, 18, 35.

13. Waterlow, J. C. Personal communication.

14. Solomon, G., and Tarver, H. The effect of diet on the rate of loss of labeled amino acid from tissue proteins. J. biol. Chem. 1952, 195, 447.

15. Kosterlitz, H. W. The effect of changes in dietary protein on the composition and structure of the liver cell. J. Physiol. (Lond.) 1947, 106, 194.

16. Campbell, R. M., and Kosterlitz, H. W. The relationship between losses in labile liver cytoplasm and urinary nitrogen excretion. Biochem. J. 1948, 43, 416.

17. Waterlow, J. C. The protein content of liver and muscle as a measure of protein deficiency in human subjects. W. Indian med. J. 1956, 5, 167.

18. Whipple, G. H., Miller, L. L., and Robscheit-Robbins, F. S. Raiding of body tissue protein to form plasma protein and hemoglobin. What is the premortal rise of urinary nitrogen? J. exp. Med. 1947, 85, 277.

19. Wainio, W. W., Eichel, B., Eichel, H. J., Person, P., Estes, F. L., and Allison, J. B. Oxidative enzymes of the liver in protein depletion. J. Nutr. 1953, 49, 465.

20. Waterlow, J. C. Observations on enzymes in the human liver. General considerations and preliminary results. Acta Un. int. Cancr. 1957, 13, 704. 